\title{
6-24 Ay Bebeği Olan Annelerin Ek Besin Tercihlerinde Sosyal Medya Kullanma Durumları ve Etkileyen Faktörlerin Belirlenmesi
}

Determination of Social Media Usage and Factors of Mothers Having Babies 6-24 Months in Supplementary Food Preference

\author{
Atiye KARAKUL ${ }^{1}$, Pınar DOĞ $\mathrm{KN}^{2}$
}

\begin{abstract}
ÖZ
Son yıllarda teknolojinin kullanımının giderek artması ile birlikte sosyal medya platformlarının kullanımı da artmıştır. Bu çalışma, 6-24 ay bebeği olan annelerin ek besin tercihlerinde sosyal medya kullanma durumları ve etkileyen faktörlerin belirlenmesi amacıyla tanımlayıcı olarak yapılmıştır. Araştırma örneklemini, Ekim 2020-Ocak 2021 tarihleri arasında 6-24 ay arasında bebeği olan 193 anne oluşturmuştur. Verilerin toplanmasında Anne/Bebek Taniticı Bilgi Formu, Ek Besin Tercihinde Sosyal Medya Kullanımı Soru Formu ve Sosyal Medya Kullanım Ölçeği kullanılmıştır. Çalışmaya katılan annelerin yaş ortalaması $29,46 \pm 4,62$ 'dir. Annelerin en çok \%64,2'sinin ek besin türlerini, $\% 59,1$ 'inin ek besin hazırlarken dikkat edilecek durumlar, \%64,2'sinin bir yaşından önce ve sonra verilebilecek ek besinleri araştırdığ saptanmıştır. Annelerin sosyal medya kullanma ölçeğinden aldıkları puan ortalaması 32,41 11 1,65'dir (min.10, maks.57). Annelerin yaşı, sosyal medya kullanma durumu, ek besinle ilgili internette yer alan bilgilerin doğru olduğuna inanma, internetten öğrenilen bilgileri ek besin hazırlarken tercih etme ile sosyal medya kullanma ölçeğinde aldıkları puan ortalaması arasinda istatistiksel olarak anlamlı bir farklılık olduğu saptanmıştır $(p<0,05)$. Çalışmanın sonucunda annelerin ek besin tercihlerinde sosyal medya kullandıkları belirlenmiştir.
\end{abstract}

Anahtar Kelimeler: Anne, Ek besin, Sosyal medya

\begin{abstract}
With the increasing use of technology in recent years, the use of social media platforms has also increased. This descriptive study was carried out in order to determine the use of social media in supplementary food preferences of mothers with 6-24 month-old babies and the influencing factors. The research sample consisted of 193 mothers who had babies between the ages of 6-24 months between October 2020 and January 2021. In collecting the data, Mother / Baby Introductory Information Form, Social Media Use Questionnaire for Supplementary Food Preference and Social Media Usage Scale were used. The average age of the mothers participating in the study is $29.46 \pm 4.62$. It was found that $64.2 \%$ of the mothers investigated the types of supplementary food, $59.1 \%$ of the cases to be considered while preparing the supplementary food, and $64.2 \%$ of the additional foods that can be given before and after the age of one. The average score that mothers got from the social media use scale is $32.41 \pm 11.65$ (min. 10, max:57). A statistically significant difference was found between the mothers' age, social media usage status, believing that the information on the internet about supplements are correct, preferring the information learned from the internet when preparing supplements and the average score they got on the social media scale $(p<0.05)$. As a result of the study, it was determined that mothers used social media in their supplementary food preferences.
\end{abstract}

Keywords: Mother, Supplementary food, Social media

Bu çalıșmanın etik kurul onayı tarih ve sayısı: 17/09/2020-882'dir.

${ }^{1}$ Dr. Öğr. Üyesi, Atiye KARAKUL, Hemșirelik Bölümü, Tarsus Üniversitesi Sağlık Bilimleri Fakültesi, atiyekarakul@gmail.com, ORCID: 0000-0001-6580-9976

${ }^{2}$ Arş. Gör., Pınar DOĞAN, Çocuk Sağlı̆̆ı ve Hastalıkları Hemşireliği AD, İzmir Katip Çelebi Üniversitesi, pnr1192@gmail.com, ORCID: 0000-0002-6943-5972 


\section{GíRiş}

Yaşamın ilk 24 ayındaki beslenme büyüme ve gelişme için oldukça önemlidir. ${ }^{1}$ Anne sütü ile besleme ve ek besinlerin başlanması bebeğin büyüme ve gelişmesi için oldukça önemlidir ve yaşamın ilerleyen yıllarında sağlık üzerinde önemli etkisi bulunmaktadır. ${ }^{2}$ Bir bebeğin enerji ve besin ihtiyacı yaklaşık altı aylıkken anne sütü ile tam olarak karşılanamaz. Bebeğin ihtiyacının karşılanabilmesi ve yeterli beslenmenin sağlanabilmesi için uygun ek besinlere geçilmesi önemlidir. ${ }^{3}$ Dünya Sağlık Örgütü (DSÖ), ilk altı ay bebeklerin sadece anne sütü ile beslenmesini, altı aydan sonra anne sütü ile birlikte 24 aya kadar güvenli ve yeterli ek besinlerle beslenmelerini önermektedir. ${ }^{4}$ Çocuklarda optimal beslenmesinin sağlanması ve sürdürülmesi için altı aydan küçük bebeklerin sadece anne sütü ile beslenmesi, 6-23 aylik bebeklerin ise anne sütü ile birlikte uygun ek gidalarla beslenmesi önerilen altın standarttır. ${ }^{5}$ Ek besine geçiş (tamamlayıcı beslenme) dönemi bebeğin anne sütü veya mama alımında kademeli bir azalmanın olduğu erişkin tip beslenmeye geçiş dönemini tanımlamaktadır. ${ }^{2,6,7} \mathrm{Bu}$ dönem bebeklerin yeni besinlere, tatlara ve beslenme deneyimlerine maruz kaldığ 1 , beslenme düzeninde belirgin değişimlerin olduğu bir süreçtir. ${ }^{8} \mathrm{Bu}$ süreçte bebeğin katı gıdalara alıştırılması kademeli bir şekilde gerçekleştirilmektedir. ${ }^{7,9}$ Dolayısıyla bu dönem bir bebeğin hayatının çok önemli bir zamanını oluşturmaktadır. ${ }^{7}$ Ek besine geçiş veya tamamlayıc1 beslenme dönemi uygulanan yöntemler, bireysel, sosyoekonomik ve kültürel koşullara göre farkl111k göstermektedir. ${ }^{10}$

Son yıllarda teknolojinin kullanımının giderek artmasıyla birlikte sosyal medya platformlarının kullanımı da artmıştır. ${ }^{11}$ Sosyal medya internet bloglarını, YouTube gibi video paylaşım sitelerini Facebook gibi Sosyal A $\breve{g}$ Sitelerini (SAS) ve çevrimiçi iletişim uygulamalarını kapsamaktadır. ${ }^{12}$ Sosyal medya son yıllarda sağlık iletişiminde de kullanılmaktadır. Sosyal medya platformları facebook ve twitter gibi bilgiye ulaşmak ve gruplarla etkileşim kurmak için firsat sunmaktadır. ${ }^{13}$ Sosyal medyanın ebeveynler tarafindan kullanılması ebeveynlerin düşüncelerini, bebek ve çocuk bakımı sonuçlarının etkilenmesine neden olabilmektedir. ${ }^{14} \quad$ Yapılan çalışmalar ebeveynlerin belirli bilgi, destek ve tavsiyeler için sosyal medya platformlarını kullandıklarını belirtmektedir. ${ }^{15,16}$

Facebook, instagram, twitter gibi forumlarda bilgi edinen ebeveynler sorumların interaktif olması nedeniyle faydalı bulmaktadır. Sosyal medyayı kullanan ve küçük çocuğu olan ebeveynlerin çoğu, ebeveynlik ile ilgili faydalı bilgileri edinmek, sosyal destek alamak ve özellikle beslenme sürecinde yașadıkları sorunlar ile ilgili sosyal medyadan destek almaktadır. ${ }^{17}$ Hachisuka ve Aksoy Sugiyama (2020) çalışmasında, annelerin bazıları ek gıdaya geçiş sürecinde özellikle çocuğuna daha sağlıklı besinleri hazırlamak ve besinlerin nasıl pişirildiğini öğrenmek ve fazla besin seçeneği sunmak için sosyal medyadan faydalandığını ifade etmiştir. ${ }^{18}$

Teknolojinin ilerlemesiyle birlikte sosyal medya platformlarının yaşamın her alanında yaygın kullanıldığı bilinmektedir. Annelerin ek besin tercihlerinde sosyal medya kullanma durumunu inceleyen çalışmalar sınırlıdır. ${ }^{17-19}$ $\mathrm{Bu}$ çalıșmanın amac1, 6-24 ay bebeği olan annelerin ek besin tercihlerinde sosyal medya kullanma durumları ve etkileyen faktörlerin (annenin yaşı, eğitim durumu, ailenin gelir düzeyi, çocuk sayısı, bebeğin cinsiyeti, bebeğin kilosu, ek besine başlama zamanı) belirlenmesidir.

\section{MATERYAL VE METOT}

Araştırma tanımlayıcı olarak yapılmıştır. Araştırma verileri pandemi nedeniyle gerçekleştirilmiş olan kısıtlamalardan dolayı sosyal medya üzerinden toplanmıştır. Veri toplamada kartopu yöntemi kullanılmıştır. Veri toplama araçları araştırmacıların sosyal medya hesaplarından paylaşılarak (facebook, instagram) toplanmıştır. Araştırma grubunu, 
Ekim 2020- Ocak 2021 tarihleri arasında 624 ay arasında (ek besine geçiş dönemi) bebeği olan 193 anne oluşturmuştur. Çalışmanın gücü "G. Power-3.1.9.2” programı kullanılarak hesaplanmıştır. 193 kişiye uygulanan analiz sonucunda, etki büyüklüğü 0,9883 olarak bulunmuş ve posthoc olarak hesaplanan çalışmanın gücü 0,99 olarak hesaplanmıştır.

Çalışmanın dahil edilme kriterleri:

1. Araştırmaya katılmaya gönüllü olma

2. 6-24 ay arasında bebeğe sahip olma

3. Bebeğin kronik bir rahatsızlığının olmamas1

\section{Sosyal ağları kullanma}

\section{Veri Toplama Araçları}

Çalışma ile ilgili verilerin toplanmasında, Anne/Bebek Tanıtıcı Bilgi Formu, Ek Besin Tercihinde Sosyal Medya Kullanımı Soru Formu ve annelerin sosyal medya kullanım durumlaırnı belirlemek için Sosyal Medya Kullanım Ölçeği kullanılmıştır.

Anne/Bebek Tanitıcı Bilgi Formu: Annenin yaş1, eğitim durumu, ailenin gelir düzeyi, çocuk sayısı, bebeğin cinsiyeti, bebeğin kilosu, ek besine başlama zamanı gibi bilgileri içeren 10 sorudan oluşmaktadır.

\section{Ek Besin Tercihinde Sosyal Medya} Kullanımı Soru Formu: Literatür doğrultusunda annenin sosyal medyanın hangi türlerini kullandığını, internette yer alan bilgilerin doğru olup olmadığı, ek besin ile ilgili sosyal medyada araştırılan konular gibi bilgileri içeren toplam altı sorudan oluşmaktadır. ${ }^{19-21}$

Sosyal Medya Kullanım Ölçeği: Johnson (2013) tarafından geliştirilen ölçek 6'lı likert tiptedir (1- Tamamen Katılmiyorum, 6Tamamen Katılıyorum). Akın ve arkadaşları (2015) ölçeğin Türkçe geçerlik ve güvenirlik çalışmasını yapmıştır. Ölçekte 8 . madde ters değerlendirilmekte, ölçeğin tamamından alınabilecek en fazla 60 puan en az ise 10 puan alınmaktadır. Ölçekten alınan puan arttıkça sosyal medya kullanım düzeyi artmaktadır. Ölçek sosyal bütünleşme ve duygusal bağlantı (SBDB) ile sosyal rutinlerle bütünleşme (SRB) alanlarında olmak üzere iki alt boyuttan oluşmaktadır. Ölçeğin ilk altı sorusu duygusal bağlantı ile sosyal bütünleşme alt boyutunu, son dört sorusu ise sosyal rutinlerle bütünleşme alt boyutunu içermektedir. ${ }^{22}$ Ölçeğin Cronbach alfa değeri SDBD alt boyutu için 0,87 ; SRB alt boyutu için 0,71 , ölçeğin tamamı için 0,87 olarak bildirilmiştir. ${ }^{23}$ Yapılan bu çalışmada ise SDBD alt boyutu için 0,93; SRB alt boyutu için 0,84 ; ölçeğin tamamı için 0,93'tür.

\section{Verilerin Değerlendirmesi}

Araştırmadan elde edilen verilerin analizi SPSS 21.0 istatistik paket programında gerçekleştirilmiştir. Çalışmaya katılan annelerin sosyodemografik özellikleri sayı ve yüzde dağılımları olarak verilmiştir. Verilerin normal dağılım uygunluğu Shapiro-Wilk normallik testi ile değerlendirilmiştir. Anne ve bebeklerin tanıtıcı özellikleri ile sosyal medya kullanma durumu arasındaki farklılık ki-kare testi kullanılarak, annelerin tanıtıcı özellikleri, sosyal medya kullanma durumları ile sosyal medya kullanma ölçeğinden aldıkları puan ortalamaları Mann Whitney U testi ile değerlendirilmiştir. İstatistiksel anlamlılık değeri $\mathrm{p}<0,05$ 'tir.

\section{Araştırmanın Etik Yönü}

Araştırmanın yürütülebilmesi için bir üniversitenin girişimsel olmayan etik kurulundan (Karar No: 882 Tarih:17.09.2020) izin alınmıştır. Araştırmaya katılan anneler, online anketin ilk sayfasında yer alan araştırmanın amacını yazan bilgilendirme formunu okuduğuna ve çalışmaya katılmayı onayladığına yönelik seçeneği işaretlemiştir. Sosyal Medya Kullanım Ölçeğinin kullanımı için Özbay'dan e-posta yoluyla gerekli izin alınmıştır. 


\section{BULGULAR VE TARTIŞMA}

Çalışmaya katılan annelerin yaş ortalamas1 29,46 44,62 'dir (minimum:19; maksimum:42). Annelerin \%53,9'unun yükseköğretim mezunu olduğu, \%48,7'sinin gelirinin gidere denk olduğu, \%54,4'ünün bir çocuğa sahip olduğu saptanmıştır.

Bebeklerin \%51,8'inin erkek olduğu, \%61,1'inin 6-12 aylık olduğu, \%87,1'inin 46 ay arasında ek gidaya başladığı, $\% 52,4$ 'ünün anne sütü ve ek gida ile beslendiği, \%92,2'sinin besinlere karş1 alerjisi olduğu saptanmıştır (Tablo 1).

Tablo 1. Anne ve Bebeklerin Tanıtıcı Özellikleri $(\mathbf{n}=193)$

\begin{tabular}{|c|c|c|}
\hline Değişkenler & Sayı & $\%$ \\
\hline \multicolumn{3}{|l|}{ Anne eğitim düzeyi } \\
\hline Okur-yazar & 1 & 0,5 \\
\hline İlköğretim & 16 & 8,3 \\
\hline Ortaokul & 12 & 6,2 \\
\hline Lise & 60 & 31,1 \\
\hline Üniversite & 104 & 53,9 \\
\hline \multicolumn{3}{|l|}{ Gelir düzeyi } \\
\hline Gelir giderden az & 57 & 29,5 \\
\hline Gelir gidere denk & 94 & 48,7 \\
\hline Gelir giderden fazla & 42 & 21,8 \\
\hline \multicolumn{3}{|c|}{ Sahip olunan çocuk sayısı } \\
\hline Bir & 105 & 54,4 \\
\hline İki & 65 & 33,7 \\
\hline Üç ve daha fazla & 23 & 11,9 \\
\hline \multicolumn{3}{|l|}{ Bebeğin Cinsiyeti } \\
\hline Erkek & 100 & 51,8 \\
\hline K1Z & 93 & 48,2 \\
\hline \multicolumn{3}{|l|}{ Bebek yașı (Aylık) } \\
\hline $6-12$ ay & 118 & 61,1 \\
\hline $13-24$ ay & 75 & 38,9 \\
\hline \multicolumn{3}{|c|}{ Ek gıdaya başlama zamanı } \\
\hline $0-4$ ay & 17 & 8,8 \\
\hline 4-6 ay & 168 & 87,1 \\
\hline $6-8$ ay & 8 & 4,1 \\
\hline \multicolumn{3}{|l|}{ Bebek beslenme șekli } \\
\hline $\begin{array}{l}\text { Anne sütü ve ek } \\
\text { g1da }\end{array}$ & 101 & 52,4 \\
\hline $\begin{array}{l}\text { Anne süt, formül } \\
\text { mama ve ek gida }\end{array}$ & 27 & 14,0 \\
\hline $\begin{array}{l}\text { Formül mama ve ek } \\
\text { gida }\end{array}$ & 29 & 15,0 \\
\hline Ek gida & 34 & 17,6 \\
\hline Anne sütü+ mama & 2 & 1,0 \\
\hline \multicolumn{3}{|l|}{ Bebeğin besin alerjisi } \\
\hline Evet & 15 & 7,8 \\
\hline Hayır & 178 & 92,2 \\
\hline Toplam & 193 & 100 \\
\hline
\end{tabular}

Annelerin \%95,3'ünün sosyal medyanın herhangi bir türünü kullandığı, \%64,2'sinin facebook kullandığı, \%28,5'inin twitter kullandığı, \%83,9'unun instagram kullandığı, \%36,8'inin youTube kullandığı, $\% 76,7$ 'sinin ek besinle ilgili internette yer alan bilgilerin doğru olduğuna inandığ1, \%83,9'unun internetten öğrenilen bilgileri ek besin hazırlarken tercih ettiği, \%46,6'sının ek besin ile ilgili sosyal medyada takip ettiği bir bloger olduğu saptanmıştır (Tablo 2).

Annelerin internetten öğrendiği bilgileri ek besin hazırlarken ne sıklıkla kullandığ sorgulandığında \%3,1'inin her zaman kullandığ $1, \% 25,9$ 'unun genellikle kullandığ \%44'ünün ara sıra kullandığı, \%21,8'inin nadiren kullandığ1, \%5,2'sinin asla kullanmadığı belirlenmiştir.

Tablo 2. Annelerin Ek Besin Tercihinde Sosyal Medya Kullanma Durumları $(\mathbf{n}=193)$

\begin{tabular}{|c|c|c|}
\hline Değişkenler & Sayı & $\%$ \\
\hline \multicolumn{3}{|c|}{ Sosyal medyanın herhangi bir türünü kullanma } \\
\hline Evet & 184 & 95,3 \\
\hline Hayır & 9 & 4,7 \\
\hline \multicolumn{3}{|l|}{ Facebook } \\
\hline Evet & 124 & 64,2 \\
\hline Hayır & 69 & 35,8 \\
\hline \multicolumn{3}{|l|}{ Twitter } \\
\hline Evet & 55 & 28,5 \\
\hline Hayır & 138 & 71,5 \\
\hline \multicolumn{3}{|l|}{ İnstagram } \\
\hline Evet & 162 & 83,9 \\
\hline Hayır & 16,1 & 16,1 \\
\hline \multicolumn{3}{|l|}{ YouTube } \\
\hline Evet & 71 & 36,8 \\
\hline Hayır & 122 & 63,2 \\
\hline \multicolumn{3}{|c|}{$\begin{array}{l}\text { Ek besinle ilgili internette yer alan bilgilerin } \\
\text { doğru olduğuna inanma }\end{array}$} \\
\hline Evet & 148 & 76,7 \\
\hline Hayır & 45 & 23,3 \\
\hline \multicolumn{3}{|c|}{$\begin{array}{l}\text { İnternetten öğrenilen bilgileri ek besin } \\
\text { hazırlarken tercih etme }\end{array}$} \\
\hline Evet & 162 & 83,9 \\
\hline Hayır & 31 & 16,1 \\
\hline \multicolumn{3}{|c|}{$\begin{array}{l}\text { Ek besin ile ilgili sosyal medyada takip edilen } \\
\text { bloger }\end{array}$} \\
\hline Evet & 90 & 46,6 \\
\hline Hayır & 103 & 53,4 \\
\hline Toplam & 193 & 100 \\
\hline
\end{tabular}

Annelerin \%46,1'inin ek besine başlama zamanını, \%31,1'inin bebeğin ek besine hazır olup olmadığını anlayabilmeye, \%64,2'sinin 
ek besin türlerini, \%48,7'sinin ilk hangi besin ile başlama, \%59,1'inin ek besin hazırlarken dikkat edilecek durumlar, \%55,4 alerji yapabilecek besinler, \%64,2'sinin bir yaşından önce ve sonra verilebilecek ek besinler, \%50,8'inin ek besin yöntemlerini (bebek liderliğinde beslenme gibi) sosyal medyada araştırdığı saptanmıştır.
Annelerin yaşı ile ek besinle ilgili internette yer alan bilgilerin doğru olduğuna inanma $\left(\chi^{2}=6,885 ; p=0,009 ; p<0,05\right)$ arasinda istatistiksel olarak anlamlı bir fark bulunmuştur (Tablo 3).

Tablo 3. Annelerin ve bebeklerin tanıtıcı özellikleri ile ek besinle ilgili internette yer alan bilgilerin doğru olduğuna inanma durumunun karşılaştırılması

\begin{tabular}{llll}
\hline & \multicolumn{3}{l}{ Ek besinle ilgili internette yer alan bilgilerin doğru olduğuna inanma } \\
Evet & $\begin{array}{l}\text { Hayır } \\
\text { Sayı / }(\%)\end{array}$ & $\begin{array}{l}\text { Sayı / }(\%) \\
\text { İstatistiksel değer }\end{array}$ \\
Anne Yașı & $98(83,1)$ & $20(16,9)$ & $\chi 2: 6,885$ \\
\hline $19-30$ yaş & $50(66,7)$ & $25(33,3)$ & p:0,009 \\
$31-42$ yaş & & & \\
\hline
\end{tabular}

\%: Yüzde

Annelerin gelir durumu ile internetten öğrenilen bilgileri ek besin hazırlarken tercih etme $\left(\chi^{2}=10,461 ; p=0,005 ; p<0,05\right)$ arasında anlamlı bir fark bulunmuştur (Tablo 4).

Tablo 4. Annelerin ve bebeklerin tanıtıcı özellikleri ile internetten öğrenilen bilgileri ek besin hazırlarken tercih etme durumunun karşılaștırılması

\begin{tabular}{|c|c|c|c|c|}
\hline \multirow[b]{3}{*}{ Gelir Durumu } & \multicolumn{4}{|c|}{ İnternetten öğrenilen bilgileri ek besin hazırlarken tercih etme } \\
\hline & Evet & Hayır & İstatistiksel değer & \\
\hline & Sayi / Puzue (70) & Sayi $/$ Muzue (70) & & $\chi 2: 10,461$ \\
\hline$\overline{\mathrm{Az}}$ & $53(93,0)$ & $4(7,0)$ & & \\
\hline Denk & $80(85,1)$ & $14(14,9)$ & & $\mathrm{p}: 0,005$ \\
\hline Fazla & $29(69,0)$ & $13(31,0)$ & & \\
\hline
\end{tabular}

\%: Yüzde

Annelerin sosyal medya kullanma ölçeğinden aldıkları toplam puan 32,41 $\pm 11,65$ 'tir (min-max:10-57). Annelerin ölçeğin sosyal bütünleşme ve duygusal bağlantı alt boyutlarından aldığı toplam puan 15,57 \pm 7,62'dir (min.6, maks.33). Sosyal rutinlerle bütünleşme alt boyut toplam puanı $16,84 \pm 4,84$ 'tür (min.4, maks. 24). Annelerin yaşı, sosyal medya kullanma durumu, ek besinle ilgili internette yer alan bilgilerin doğru olduğuna inanma, internetten öğrenilen bilgileri ek besin hazırlarken tercih etme ile sosyal medya kullanma ölçeği toplam puan ortalamas1 arasında istatistiksel olarak anlamlı bir farklılık olduğu saptanmıştır $(\mathrm{p}<0,05)$ (Tablo 5). Annelerin yaşı, sosyal medya kullanma durumu, ek besinle ilgili internette yer alan bilgilerin doğru olduğuna inanma, internetten öğrenilen bilgileri ek besin hazırlarken tercih etme durumu ile sosyal medya kullanma ölçeğinin alt boyutlarının karşılaştırılması Tablo 5'te gösterilmiştir. 
Tablo 5. Sosyal medya kullanma ölçeğinde alınan toplam puan ve alt boyutlarının annelerin ek besin tercihinde sosyal medya kullanma durumları ile karşılaştırılması

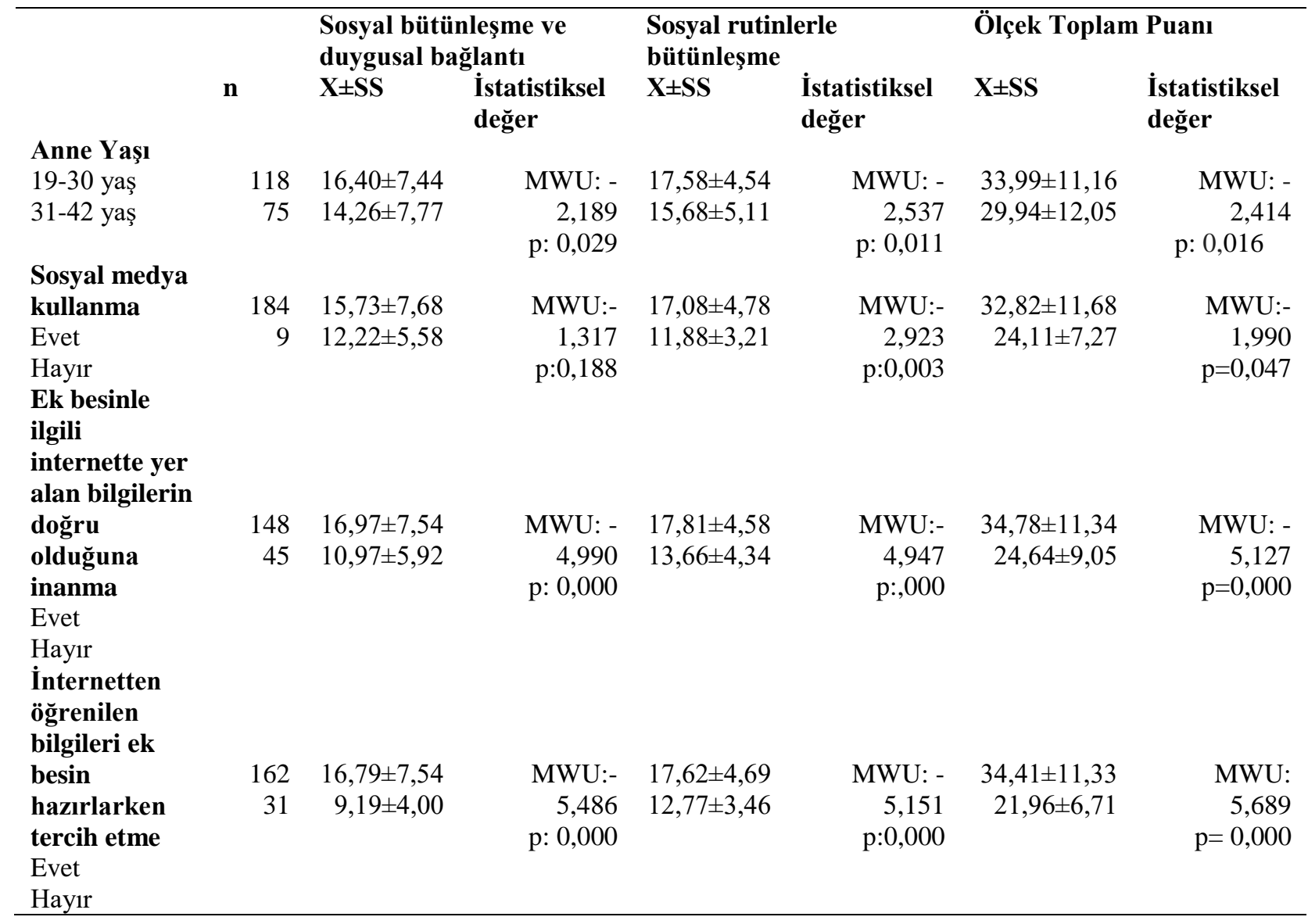

* $\mathrm{X} \pm \mathrm{SS}$ : Ortalama \pm Standart Sapma, **Mann - Whitney U testi

Gelişen teknoloji ve sosyal medya kullanımın artmasıyla birlikte anneler birçok konuda olduğu gibi ek besin ile ilgili konularda da sosyal medyadan yararlanmaktadır. ${ }^{24}$ Yapılan bu çalışmada, 624 ay bebeği olan annelerin ek besin tercihlerinde sosyal medya kullanma durumları ve etkileyen faktörler incelenmiştir.

Anne sütü, bebeğin ihtiyacı olan tüm besin öğelerini içermektedir. $\mathrm{Bu}$ nedenle annelerin bebeklerini, ilk altı ay sadece anne sütü ile beslemesi oldukça önemlidir. Yapılan bu çalışmada annelerin \%8,8'i dördüncü aydan önce, \%87'si ise 4-6 ay arasında ek gıdaya başlamıştır. Literatürde bu konu ile ilgili yapılan çalışmalarda annelerin \%42,2'si dördüncü aydan önce, \%52,8'inin 4-6 aylar arasında ek besine geçmiştir. ${ }^{20}$ Daha önce yapılan çalışmalarda altıncı aydan önce ek besine başlayan annelerin yüzdesi Gümüştakım ve ark.'nın (2017) çalışmasında ${ }^{21} \quad \% 25,6$; Yılmaz'ın (2020) çalışmasında ${ }^{25} \quad \% 26,0, \quad$ Sivri (2014) çalışmasında ${ }^{26} \% 32,4$; Küçük ve Göçmen'in (2012) çalışmasında ${ }^{27} \% 23,2$; Durmuş ve ark.'nın (2020) çalışmasında ise \%42,5'tir. ${ }^{28}$ TNSA 2018 verilerinde ise annelerin $\% 12$ 'sinin altınc1 aydan önce ek besine başladığı belirtilmiştir. ${ }^{29} \mathrm{Bu}$ çalışmanın sonucu Türkiye ortalamasından yüksek olmakla birlikte diğer çalışmalarla benzerlik göstermektedir. $\mathrm{Bu}$ nedenle anneler başta olmak üzere toplumun da ek besine başlama zamanı konusunda geliştirilmeye gereksinimi vardir.

Sosyal medyanın sosyal destek olarak kullanımının kolay olmasi, her an ve her saatte/ya da 7 gün 24 saat ulaşılabilir olması nedeniyle anneler tarafindan kullanımı giderek artmaktadır, ancak doğru ve güvenilir kaynaklardan bilgiye ulaşabilmek önemli bir yere sahiptir. ${ }^{16}$ Moon ve ark. (2019) 28 anne ile yaptıkları nitel çalışmada, annelerin internet ve sosyal medyayı bilgiye ulaşmanın bir yolu olarak gördüklerini, 
internetteki bilgileri genel olarak güvenilir bulduklarını ortaya koymuştur. ${ }^{17}$ Ünsal ve ark. (2005) 5003 anne üzerinde yaptıkları bir çalışmada annelerin \%11,5'inin medya tarafindan bilgilendiklerini bildirmiştir. ${ }^{30}$ Durmuş ve ark. (2020) yapmış olduğu çalışmada, annelerin \%5'inin anne sütü hakkında bilgi aldıkları yerin basın olduğunu ifade ettiğini belirtmiştir. ${ }^{28}$

$\mathrm{Bu}$ çalışmada, annelerin çoğunluğu internette yer alan bilgilerin doğruluğuna inandığını ve ek besin hazırlarken sosyal medyadan yararlandığını belirtmiştir. Anneler sosyal medyada en çok ek besin türlerini, bir yaşından önce ve sonra verilebilecek ek besinleri, ek besin hazırlarken dikkat edilecek durumları, alerji yapabilecek besinleri, ek besin yöntemlerini ve ek besine başlanması gereken ilk besinleri araştırdığı görülmüştür. Ek olarak sosyal medya ölçek puanı yüksek olan annelerin, sosyal medyada ek besinle ilgili internette yer alan bilgilerin doğruluğuna inandiğı ve ek besin hazırlarken tercih ettiği belirlenmiştir. Taplak ve ark. (2020) yapmış oldukları nitel çalışmada, bir anne ek gıdaya başlama zamanı geldiğinde “...kendim araştırdım internetten bu beslenme sitelerinden..." ifade etmiştir. ${ }^{31}$ Yaman'ın (2018) 10 anne ile derinlemesine görüşme yöntemi ile yapmış olduğu çalışmada bir anne "...Çocuğumun beslenmesiyle ilgili... konularda ihtiyaçlarıma cevap veriyor." şeklinde ifade etmiştir. ${ }^{18}$ Hachisuka ve Sugiyama (2020) beslenme üzerine sosyal medya anneleri ile yapmış olduğu nitel çalışmada, annelerin çocuğunun beslenmesinde sosyal medyadan bilgi aldığını belirlenmiştir. Bir anne “...özellikle bir tane site var, çocukların beslenmesi ile ilgili öneriler aylara yönelik şeyler veriyor. $\mathrm{Bu}$ ayda şunlara başlayabilir, bu ayda bunlart yiyebilir, şu yemeğe bunlart bunlart katabilirsiniz, şunlarl verebilirsiniz tarzı onlardan faydalanıyordum fikir alıyordum" şeklinde ifade etmiştir. ${ }^{19}$

$\mathrm{Bu}$ çalışmada yer alan annelerin yaş ortalamasının düşük, eğitim durumunun ve gelir düzeyinin iyi olduğundan annelerin bebekleri için sosyal medya platformu aracılığıyla bilgiye hızlı bir şekilde ulaşmaya çalıştığını göstermektedir. Aynı zamanda sosyal medya platformlarında yer alan öneriler diğer anneler tarafından daha önce deneyimlenmiş olduğu için anneler burada yer alan bilgileri kullanmayı tercih ediyor olabilir.

Teknolojiyle birlikte kişilerin birbirine ve bilgiye kolay ulaşabilmesi sayesinde sosyal medya kullanımı giderek artmıştır. Yapılan bu çalışmada annelerin sosyal medya kullanım düzeyinin ortalamanın çok az üstünde olduğu belirlenmiştir. Annelerin yaşı, sosyal medya kullanma durumu, ek besinle ilgili internette yer alan bilgilerin doğru olduğuna inanma, internetten öğrenilen bilgileri ek besin hazırlarken tercih etme durumlarının sosyal medyayı kullanım düzeyini etkilemektedir. Araştırmada yer alan annelerin çoğunluğu "Y" kuşağ1 annesidir. Dolayısıyla bu kuşak anneler, internetle iç içe yaşamlarını sürdürmüşlerdir. İlgi duydukları konularda sosyal medya platformlarında araştırma yapmakta, internete yer alan bilgileri kullanmadan önce yapılan yorumları ve deneyimleri dikkate almaktadır. Buna bağlı olarak "Y" kuşağı annelerin, sosyal medyayı kullanım düzeyi fazladır. 32,33 Araştırma bulguları, "Y" kuşağının özelliklerine uygun olduğunu göstermektedir.

\section{Sinırlılıklar}

Araştırmanın bazı sınırlılıkları vardır. Araştırma verilerinin online platformda toplanmış olması nedeniyle düşük eğitim seviyesindeki annelere ulaşmakta güçlük yaşanmıştır. $\mathrm{Bu}$ nedenle annelerin eğitim seviyesinin değişkenlik gösterdiği örneklemde araştırmanın yenilenmesi önerilmektedir. Bir diğer sinırlılık ise araştırma sorularında sosyal medyada kullandıkları bilgi kaynağının özelliklerini ve annelerin altıncs aydan önce ek besine başlama nedenin tıbbi olup olmadığı yer almamaktadır. $\mathrm{Bu}$ doğrultuda çalışmanın sonuçları tüm evrene genellenemez. 


\section{SONUÇ VE ÖNERILLER}

Çalıșmanın sonucunda annelerin sosyal medya kullanım düzeyinin ortalamanın üzerinde olduğu ve ek besin tercihlerinde sosyal medyayı kullandıkları belirlenmiştir. Anneler sosyal medyada araştırdığı en çok konular; bir yaşından önce ve sonra verilebilecek ek besinleri, ek besin hazırlarken dikkat edilecek durumları, alerji yapabilecek besinleri, ek besin yöntemlerini ve ek besine başlanması gereken ilk besinlerdir. Ek olarak annelerin yaş1, sosyal medya kullanma durumu, ek besinle ilgili internette yer alan bilgilerin doğru olduğuna inanma, internetten öğrenilen bilgileri ek besin hazırlarken tercih etme durumlarının sosyal medyayı kullanım düzeyini etkilemektedir. Günümüz dünyasında dijital bağımlılık büyük bir risk haline gelmektedir. Annelerin dijital bağımlılıktan korunması ve dijital okuryazarlık düzeylerinin geliştirilmesi oldukça önemli bir yere sahiptir. Hemşirelerin özellikle ek besine geçiş gibi annelerin desteğe ihtiyaç duyduğu konularda önceliğin sağlık kurumları olması ve güvenilir kaynaklardan bilginin araştırılması konularını vurgulaması gerekmektedir.

KAYNAKLAR

1. Karadağ, M, Aydın, S, Yılmaz, Y. ve Elmas, S. (2016) "Altı Aydan Küçük Bebeklerin Emzirilme Özellikleri". STED, 25 (1), 22-27.

2. Alvisi, P, Brusa, S, Alboresi, S, Amarri, S, Bottau, P, Cavagni, G, Corrdini, B, Lnadi, L, Loroni, L, Marani, M, Osti, M.I, Povesi-Dascola, C, Caffarelli, C, Valeriani, L. and Agostoni, C. (2015). "Recommendations on Complementary Feeding for Healthy, Full-Term Infants". Italian Journal of Pediatrics, 41 (1), 1-9.

3. WHO. (2021). "Complementary Feeding". Erişim adresi: https://www.who.int/health-topics/complementaryfeeding\#tab=tab_1 (Erişim tarihi: 20-02-2021)

4. WHO. (2021). "Breastfeeding". Erișim adresi: https://www.who.int/healthtopics/breastfeeding\#tab=tab _2 (Erişim tarihi: 20-02-2021)

5. Thet M.M, Richards L.M, Sudhinaraset M, Paw, N.E.T. and Diamond-Smith, N. (2016). "Assessing Rates of İnadequate Feeding Practices Among Children 12-24 Months: Results From A Cross-Sectional Survey in Myanmar". Maternal and Child Health Journal, 20 (8) 1688-1695.

6. EFSA Panel on Dietetic Products, Nutrition and Allergies (NDA). (2009). "Scientific Opinion on the Appropriate Age for İntroduction of Complementary Feeding of Infants". EFSA Journal, 7 (12), 1423.

7. D'Auria, E, Bergamini, M, Staiano, A, Banderali, G, Pendezza, E, Penagini, F, Zuccoti, G.V. and Peroni, D. G. (2018). "Baby-led Weaning: What a Systematic Review of the Literature Adds on". Italian Journal of Pediatrics, 44 (1), 49.

8. Fewtrell, M, Bronsky, J, Campoy, C, Domellöf, M, Embleton, N, Mis, N.F, Hojsak, I, Hulst, J.M, Indrio, F, Lapillonne, A. and Molgaard, C. (2017) "Complementary Feeding: a Position Paper by the European Society for Paediatric Gastroenterology, Hepatology, and Nutrition (ESPGHAN) Committee on Nutrition". Journal of Pediatric Gastroenterology and Nutrition, 64 (1), 119-132.

9. Kaya, Z, Yiğit, Ö, Erol, M. ve Gayret, Ö.B. (2016) "Alt1-Yirmi Dört Ay Arası Yaş Grubunda Beslenmeyle İlgili Anne ve Babaların Bilgi ve Deneyimlerinin Değerlendirilmesi”. Medical Bulletin of Haseki/Haseki Tip Bulteni, 54 (2), 70-75.

10. Arikpo, D, Edet, E.S, Chibuzor, M.T, Odey, F. and Caldwell, D.M. (2018). "Educational Interventions for Improving Primary Caregiver Complementary Feeding Practices for Children Aged 24 Months and Under". Cochrane Database of Systematic Reviews, 5, 3.
11. Doub, A.E, Small, M. and Birch, L.L. (2016). "A Call for Research Exploring Social Media Influences on Mothers' Child Feeding Practices and Childhood Obesity Risk". Appetite, 99, 298-305.

12. Aichner, T. and Jacob, F. (2015). "Measuring the Degree of Corporate Social Media Use". International Journal of Market Research, 57 (2), 257-276.

13. Russell, D.J, Sprung, J, McCauley, D, de Camargo, O.K, Buchanan, F, Gulko, R, Martens, R. and Gorter, J.W. (2016). "Knowledge Exchange and Discovery in The Age of Social Media: The Journey from Inception to Establishment of a Parent-Led Web-Based Research Advisory Community for Childhood Disability". Journal of Medical Internet Research, 18 (11), e293.

14. Pretorius, K, Johnson, K.E. and Rew, L. (2019). "An Integrative Review: Understanding Parental Use of Social Media to İnfluence Infant and Child Health". Maternal and Child Health Journal, 23 (10), 1360-1370.

15. DeMartini, T.L, Beck, A.F, Klein, M.D. and Kahn R.S (2013). "Access to Digital Technology Among Families Coming to Urban Pediatric Primary Care Clinics". Pediatrics, 132 (1), 142-148

16. Baker, B. and Yang I. (2018). "Social Media as Social Support in Pregnancy and The Postpartum". Sexual \& Reproductive Healthcare, 17, 31-34.

17. Moon, R.Y, Mathews, A, Oden, R. and Carlin R. (2019). "Mothers' Perceptions of the Internet and Social Media as Sources of Parenting and Health Information: Qualitative Study". Journal of Medical Internet Research, 21 (7), e14289

18. Yaman, E.S. (2018). "Ürün Yerleștirmede Yeni Bir Alan: İnfluencer Marketing Sosyal Medyada İnfluencer Annelerin Takipçileri Tarafından Değerlendirilmesine Yönelik Bir Araștırma”. Uluslararası İletişimde Yeni Yönelimler Konferansı, 268-279.

19. Hachisuka, R. and Sugiyama, C.A. (2020). "Ben Çocuğumu Böyle Besliyorum! Beslenme Konusunda Sosyal Medya Anneleri Üzerine bir Değerlendirme". Uluslararası İnsan Calışmaları Dergisi, 3 (5), 123-142.

20. Beşbenli, K, Aygen, B, İncioğlu, A. ve Çetinkaya F. (2013). "İstanbul'da Üc Farklı Sosyoekonomik Grupta Yer Alan Annelerin Emzirme ve Bebek Beslenmesi Konusundaki Bilgi ve Davranışları”. Çocuk Sağlığı ve Hastalıkları Dergisi, 56, 76-81.

21. Gümüştakım, R.Ş, Aksoy, D.H, Cebeci, S.E, Kanuncu, S, Cakır, L. ve Yavuz E. (2017). "0-2 Yas Cocuklarda Beslenme Alışkanlıklarının Değerlendirilmesi: Çok Merkezli Calıșma”. Fam Pract Palliat Care, 2 (1), 1-8. 
22. Jenkins-Guarnieri, M.A, Wright, S.L and Johnson, B. (2013). "Development and Validation of a Social Media Use Integration Scale". Psychology of Popular Media Culture, 2 (1), 38.

23. Akın, A, Özbay, A. ve Baykut, İ. (2015). "Sosyal Medya Kullanımı Ölçeği'nin Türkçe Formu'nun Geçerliği ve Güvenirliği”. Journal of International Social Research, 8 (38), 2.

24. Lebron, C.N, George, S.M, Eckembrecher, D.G. and Alvarez, L.M. (2020). "Am I Doing This Wrong?" Breastfeeding Mothers' Use of an Online Forum. Maternal \& Child Nutrition, 16 (1), e12890.

25. Y1lmaz, G. (2020). "0-24 Aylık Bebeklerin Beslenme Şekillerinin İncelenmesi”. Gümüşhane Üniversitesi Sağlık Bilimleri Dergisi, 8 (4), 343-352.

26. Sivri, B.B. (2014). "0-6 Aylık Bebeği Olan Annelerin Katı Gıdaya Geçiş Süreci ve Emzirmeye İlişkin Bilgi ve Uygulamaları". ACU Sağlık Bil Dergisi, 5 (1), 59-65.

27. Küçük, Ö. ve Göçmen, A.Y. (2012). "Çocuk Polikliniğine Başvuran 6-24 Ay Arası Sağlam Cocukların Değerlendirilmesi”. Bakırköy Tıp Dergisi, 8 (1), 28-33.

28. Durmuş, S.Ç, Ceylan, M, Candoğan, M, Öztunç, C, Güner, M, Demir, İ. ve Cankaloğlu H. (2020). "Annelerin 0-24 Aylı Çocuklarını Besleme Davranışları: Kırıkkale İli Örneği”. Sağlık ve Toplum, 20 (1), 52-60.

29. Türkiye Nüfus ve Sağlık Araştırması (2018). "2018 Türkiye Nüfus ve Sağlık Araştırması”. Erişim adresi: http://www.hips.hacettepe.edu.tr/tnsa2018/rapor/TNSA2 018 ana Rapor.pdf (Erișim tarihi: 01-02-2021)

30. Ünsal, H, Atlıhan, F, Özkan, H, Targan, Ş. ve Hassoy, H (2005). "Toplumda Anne Sütü Verme Eğilimi ve Buna Etki Eden Faktörler". Çocuk Sağlığı ve Hastalıkları Dergisi, 48 (3), 226-233.

31. Taplak, A.S, Polat, S, Erdem, E. ve Taplak, M. (2020). "Annelerin Tamamlayıcı Beslenmeye Geçiş Sürecinde Yaşadıkları Güçlükler: Niteliksel Çalışma”. JAREN, 6 (2), 300-308.

32. Sarıtaş, E. ve Barutçu, S. (2016). "Tüketici Davranıșlarının Analizinde Kuşaklar: Sosyal Medya Kullanımı Üzerinde Bir Araştırma”. PJESS, 3 (2), 1-15.

33. Kuyucu, M. (2014). "Y Kuşağı ve Facebook: Y kuşağının Facebook Kullanımı". Elektronik Sosyal Bilimler Dergisi, 13 (49), 55-83. 